\title{
Reflective Tools in an English Language Teaching Context: Contributions, Challenges and Recommendations ${ }^{1}$
}

\author{
Hülya TUNCER \\ Dr., Çukurova University \\ Faculty of Education, English Language Teaching Department \\ hulyatncr@gmail.com \\ Orcid ID: https://orcid.org/0000-0001-8536-6471

\section{Yonca ÖZKAN} \\ Prof. Dr., Çukurova University, \\ Faculty of Education, English Language Teaching Department \\ yoncacaylakliozkan@gmail.com \\ Orcid ID: https://orcid.org/0000-0001-5279-4568
}

\begin{abstract}
Learning and teaching are the essential inseparable components of any educational contexts, both of which can be facilitated by the utilization of reflective tools. Such tools enhance learners' reflective thinking skills which constitutes a solid base for constructivist learning settings. Constructivist language learning environments require teachers and learners to reflect on classroom dynamics utilizing appropriate tools. There are numerous reflective teaching tools to encourage the learners to learn more, research more, and be more open and curious about learning elements. Once these tools are utilized at an optimum level, the educational settings would yield fruitful and constructive outputs. From a constructivist stance, this study reviews four reflective tools diaries, videos, portfolios/e-portfolios, and blogs- concerning ELT and language teacher education. This study involves a descriptive and comprehensive look by highlighting each reflective tool's impact on the partakers of the targeted educational settings. The study also presents some guidelines on how to utilize and integrate those reflective tools in ELT contexts.
\end{abstract}

Anahtar Kelimeler: Reflective Learning, Reflective Tools, Diary, Video, Portfolio/e-portfolio, Blog.

\footnotetext{
${ }^{1}$ Article Arrival/Acceptance Date: 08.01.2020 / 18.04.2021

Reference Information: Tuncer, H. and Özkan, Y. (2021). Reflective tools in an English language teaching context: contributions, challenges and recommendations. Kahramanmaraş Sütçü Imam University Journal of Social Sciences, 18(1), 181-204. DOI: 10.33437/ksusbd.671482
} 


\title{
İngiliz Dili Eğitimi Bağlamında Kullanılan Yansıtıcı Öğretim Araçları: Katkıları, Sınırlılıkları ve Öneriler
}

\begin{abstract}
Öz
Öğrenme ve öğretim birbiriyle iç içe geçmiş kavramlar olup her ikisi de yansıtıcı öğretim araçları ile pekiştirebilmektedir. Bu türdeki öğretim araçları yabancı dil öğrencilerinin yansıtıcı düşünce becerilerini geliştirerek onların daha sağlam temellerle düşünce gücünü artırmada ivme kazandırmaktadır. Yapılandırmacı Öğrenme Kuramı bağlamında gerek öğretmen gerek öğrenciler yansıtıcı araçlarla sınıf içi yansıtıcı düşünce ortamına katkıda bulunabilmektedir. Alanda, farklı özelliklerde yansıtıcı öğretim araçları mevcuttur. Yansıtıcı öğretim araçları, eğitim ortamında en uygun şekilde kullanıldığında eğitim öğretim ortamına verimli çıktılar sağlamaktadır. Bu çalışma, Yapılandırmacı Kuram Bağlamında dört ana yansıtıcı öğretim aracını (günlük, video, portfolyo/eportfolyo, blog) İngiliz Dili Eğitimi ve İngilizce öğretmeni yetiştirme bağlamında ele almaktadır. Bu çalışma, anılan bu yansıtıcı öğretim araçlarının dil öğrenimi ve öğretmen yetiştirme üzerine etkisini betimleyici bir bakış açışıyla eğitim düzleminde çok yönlü ele almaktadır. Ayrıca, çalışma yansıtıcı öğretim araçlarının sınıf ve sınıf dışı düzlemlerde nasıl kullanılabileceğini içeren tavsiyelere de yer vermektedir.
\end{abstract}

Keywords: Yansıtıcı Öğretim, Yansıtıcı Öğretim Araçları, Günlük, Video, Portfolyo/e-portfolyo, Blog.

\section{INTRODUCTION}

Reflectivity is one of the merits manifested as the fingerprint of professional competence. Even though this competence was defined by numerous scholars, Dewey (1933) was the one who first identified the reflective thinking as "active, persistent, and careful consideration of a belief or supposed form of knowledge in the light of the grounds which support it and the further conclusions to which it tends" (p.118). Black (2015) also defines reflective practice as a tool to determine and improve teachers' competence, performance, and self-efficacy. Like Schön's (1984) reflection-in-action, reflection-on-action, and reflection-foraction (Van Manen, 1991), a reflective practitioner should consider the past, present and future practices first to understand weaknesses and strengths and improve and bring a change for the enhancement of any educational context.

Reflective practice is on the rise in the educational atmospheres where professional development is given the utmost importance to fulfil the standards of the digitalized era. English language use has been changing rapidly, and this 
shift highly influences language education settings. To better consolidate the latest trends in language education, the targeted reflective tools would be of use for the realization of the needs of the era.

To accomplish the objectives of the study, the following phases are realized:

1) Develop a strategy for the literature research, 2) Select studies a) that use the reflective tools -diary, video, portfolio/e-portfolio, and blog- within their keywords section, b) that were published after 2000, c) that were published in the journals included in international indexes within the scope of ELT, d) two of which were published in Turkey while three of which were published outside Turkish context, 3) Discuss each study by delving into participants, research design and setting, data collection tools, and the findings, and 4) Provide the contributions, challenges and recommendations of each reflective tool.

With this critical review of the reflective tools utilized in various ELT settings, it is aimed to clearly present the contributions and challenges in utilizing four reflective tools -diaries, videos, portfolios/e-portfolios, and blogs- within the domain of language education. Also, some practical recommendations are given so that language teachers, learners, and researchers in the targeted field would benefit to a large extent. The teachers are supposed to gain benefit by observing the potential uses of reflective tools, and this study would enable teachers to choose the most appropriate pedagogical tool(s) to meet learners' needs and interests with respect to their age and proficiency levels. Students would gain much by modeling the targeted reflective tools into their learning contexts and transferring those tools into their learning and teaching environment. Thus, they would be provided with an opportunity to freely express their voices using these reflective platforms inside and outside the classroom. Finally, researchers within the field of English language teaching and in the field of teacher education would benefit by consolidating what has been done so far and how to proceed from those points.

\section{DIARY STUDIES}

Diaries have been extensively benefitted from within language learning and teaching contexts. Bailey and Ochsner (1983) delineate this reflective tool by stating that "[a] diary study in second language learning, acquisition, or teaching is an account of a second language experience as recorded in a first-person journal" (p.189). To enhance language learning and teaching environments, five representative diary studies are scrutinized in the following paragraphs.

Basing their study on the theory that learning strategies are affected by learner styles and vice versa, Ma and Oxford (2014) conducted a diary study with an advanced ESL learner. To provide useful background information, the learner 
(diarist) was given a learning style survey and a learning strategy survey before their study. During the study, the diarist took two graduate-level education courses that emphasized learning by listening and speaking and therefore required the learners to have discussions. The diarist used abbreviated note-taking method during class hours, and she transformed those in-class notes into diary entries within a few hours or more. She kept the learning strategy diary for 85 days, and the end-product was a diary consisting of 18 entries with various lengths. Analysis of these diary entries gave consistent results regarding the diarist's learning style and the learning strategies, indicating those styles and strategies were interconnected. The findings also show that learners can leap out of their comfort zone and seek new things to fulfill their communicative goals, and they can use a combination of learning styles to reach their goals. Such diary studies give the language teachers the opportunity to recognize the individual differences and to pair the students with the ones who have a different learning style. The researchers conclude by stating that language teachers should devote a strenuous and sustained effort to respond to all types of learning styles in the class.

Diary studies can be utilized with a larger group of learners, as well. For instance, Lee and Lew (2001) conducted a study with four MA students enrolled in a program for teaching English to speakers of other languages (TESOL) in Southern California. With the aim of identifying the anxieties and coping strategies of nonnative English speaking (NNES) students and detecting how they view their strong points, the study focused on the two courses: English as a foreign language (EFL) and English as a second language (ESL). Despite the differences in the participants' professional goals and/or their English language learning background, the diaries, together with an interview conducted at the end of the study yielded four common themes:

1- A high level of language anxiety: Being aware that they were NNES students affected their perception of themselves, which clearly impaired their performance in language skills.

2- Feeling of inferiority: Comparing themselves with their native speaker peers made NNES students believe that native speakers do not have to work as hard as themselves.

3- Anxiety for reading and writing skills: The participants expressed their anxiety, especially for reading and writing skills more than the speaking skills.

4- Their experience as English learners (the most valuable asset of NNES students): The participants expressed that their experience as learners of English is the most valuable strength that they bring to the TESOL Program. They stated that with the help of that experience, they can understand what their future students might go through in learning English. 
On the issue of the coping strategies for the anxieties, it was found that some students asked for the support of their NES peers to perform better in class, and some others spent extra time for reading and writing tasks. The majority of the world's EFL and ESL teachers consist of NNES teachers and understanding their anxieties and coping strategies is fruitful for language learners and teachers. The stakeholders of the TESOL programs also benefit from such studies to address the students' reading and writing anxieties and reducing them properly.

Diary studies pave a better way not only for students and teachers but also for course organizers. For instance, Krishnan and Hoon (2002) conducted a diary study with foreign freshmen students studying in an intensive English language programme in Singapore. Consisting of mainly Malaysian and Indonesian background, the students were new to Singaporean culture, and the study aimed at the improvement of teaching and learning environment within such a multicultural classroom. The analysis of diary entries yielded three issues: Move anxiety, Learner agenda, and Learning environment. 'Move anxiety' is related to the students' ability/inability to adapting to a new environment. 'Learner agenda' is defined as the perception of the learner as to the things s/he wants to learn, and 'learning environment' refers to the context where learning takes place. Within those three issues, the learners reflected that they had difficulties performing even everyday activities in a new place, and they had different learner agendas. Besides, they placed great importance on the teacher's personality and the teaching method. This study not only described the issues in a multi-cultural classroom but also embraced some suggestions for a better handling of such issues.

Diaries are also useful for tracing the possible changes in the beliefs of preservice teachers. For this very aim, Debreli (2011) conducted a diary study with three Turkish pre-service teachers during the training period. The diaries were submitted to the participants at the beginning, during and at the end of the training. The analysis of the diary entries proved that they allowed an easy track of the participants' beliefs as to language teaching and learning. Besides, they formed valid data in which the participants justified interpretations of their own experiences. Except for some minor problems such as the inclusion of some irrelevant information, the diaries were proved to accomplish the targeted objectives.

Diaries can be used not only at the tertiary level but also in secondary and high school settings. One such study was conducted with 7th grade students in the Turkish context (Kir, 2012). Intending to gather the views of the students as to the good and the bad sides of her language lesson, the teacher/researcher requested her students to keep a diary for 13 weeks where they would write about whether the class was good or not together with the rationale behind. They would 
also touch upon their feelings about the class, the teacher and their classmates. The students wrote in their native language -Turkish-, and they were free to write both during and after the lesson. The researcher herself kept a diary focusing onsimilar issues, but she also wrote about the difficulties the students experienced. The data analysis of the students' and the teacher's diaries yielded both similar and different themes with a varying frequency. Both parties highlighted the importance of 'classroom management' and 'enjoyable lessons'. They stressed that if and when the classroom is managed well, and an element of fun is included, then the lesson goes well. While the teacher emphasized 'lesson planning', 'motivational level of the students', and 'course materials', the students' priority was on 'the role of a teacher', and 'the relation of the course content to the real life'. The study offered valuable insights into both the teacher's and the students' perceptions of a good language lesson.

\section{Contributions of Diary Studies}

" Diaries pave the way for introspection; in comparison to the other data collection tools, diaries could elicit the personal feelings, emotions and opinions of the participants more easily.

» Regular diary-keeping process yields synchronous data, which prompts the collection of multiple views on the same event or the same date.

» Diaries embedded with peer checking process enable the learners to receive feedback not only from their teachers but from their peers as well.

" Diary studies are not time and place-bound, so the participants can write at their own pace (within the confines of the study) and wherever they choose.

" Diaries provide self-awareness related to teaching practices as well as learning styles and choices of the learners.

\section{Challenges in Conducting Diary Studies}

» The diarist may diverge from the scope of the study and write about irrelevant issues.

» The diarist may not develop a habit for writing the diary regularly.

» Due to its qualitative nature, the diary studies cannot be easily generalized since the data mainly comprises a small number of cases.

» The diarists may not commit themselves into the diary-keeping process, so the diary entries may not reflect their true feelings or opinions. 
》 Due to the memory constraints, the diarists cannot fully recall the events unless they write immediately after the experience.

\section{Recommendations for Conducting Diary Studies}

" The aims of the study should be stated very carefully at the beginning, and those aims should be communicated to the participants.

" The researcher should familiarize the participants with a diary keeping process. For this reason, providing a few sentences or an example diary entry might work at the onset of the process.

" Regular checks of diary entries are suggested to keep the diarists on the desired track.

" The native language of the diarists might be preferred in diary keeping as they might feel at ease in stating their own feelings and opinions.

" For ensuring reliability, diary entries should be analyzed by another researcher/colleague as well.

» Diaries could be supported by another research tool such as interviews to justify the content of the diary entries better.

\section{VIDEO STUDIES}

The use of video to delve into the key components of language education through a critical perspective has gained popularity. It deserves to be labelled as one of the crucial research tools of reflectivity. The following five studies are representative of how a video enhances the reflective thinking process within the framework of language learning and teaching.

To assist the Turkish teacher trainees through the practicum period, Eröz-Tuğa (2013) conducted a study in which ELT students reflect on their video-recorded teaching sessions. Since the pre-service teachers -most of the time- get grades and evaluations from their mentors and supervisors towards or at the end of the practicum, they do not have so many opportunities to reflect on their teaching, learn from their mistakes and implement the pieces of advice of their trainers. However, this study gave them a chance to perform those actions before the end of the practicum. Eleven volunteered students were observed twice during the practicum semester, and those videotapes were analyzed by the participant herself/himself, her/his peer partner, and the supervisor/researcher. During these sessions, they used a feedback form focusing on: a) classroom management, b) classroom persona and self-presentation, and c) classroom procedures and lesson planning. The data collected from the recorded feedback sessions and the written 
self-evaluation reports of the participants were analyzed to see the possible changes or improvements. The researcher detected a significant increase in the participants' awareness into their weak and strong points in the classroom context. Besides, receiving feedback before their final performance reduced their stress while promoting their self-confidence. This study proved that 'showing' instead of 'telling' the crucial points in the videos facilitated the practicum process.

In the Turkish context, Susoy (2015) video recorded 45-minute teaching session of three pre-service teachers in the public school during their practicum. With the aim of promoting reflectivity and scrutinizing the perceptions of the trainees as to viewing their own teaching, the researcher gave them a guiding sheet for a self-analysis. With a reflective journal and an open-ended questionnaire, the data demonstrated that the trainees encountered some problems regarding the correct L2 use. Another detected problem is related to being unfamiliar with the style of the mentor and the profile of the students. The preservice teachers also became aware that their mood is reflected in the classroom atmosphere, i.e. when they are sick or tired, they do not interact with the students efficiently. What is more, all three participants came to an understanding of a reflective process and went through some changes in their teaching due to questioning and thinking critically. In sum, the study showed that watching themselves and discussing the teaching session with their peers, and the supervisor provided pre-service teachers with a way of improving themselves.

As a researcher who defends the idea that reflective teaching practices should be integrated into second language teacher education curricula as early as possible, Orlova (2009) conducted a video study with pre-service teachers to incite a reflectivity process. She initiated a five-step reflective process: preparing and then videotaping the micro-teaching, self-viewing, repeated self-viewing and reflection, viewing the record with a peer, and viewing with a supervisor. For the third step, the researcher submitted some written questions to stimulate the trainees' reflection. At the end of the study, it was observed that the trainees showed an increase in their self-awareness, specifically about their teaching profiles. The reflection through the video sessions also caused a role-shift; a transition from a 'focus on themselves' stage into 'learners' needs and behaviours'. In addition to the outcomes mentioned above, the study planted the idea that reflectivity is not a single completed action but a continual and crucial component of teaching.

To discover what kind of elements the pre-service teachers focus on while watching themselves through video records, Payant (2014) conducted a study with the practicum course students registered at MATESOL program in the United States. The pre-service teachers of the study consisted of five non-native speakers with Chinese, Taiwanese, and Japanese backgrounds. They prepared 
and taught two lessons: first to their peers and then to the ESL classrooms they were observing. After each lesson, all of the participants provided both written and oral feedback. Besides, the micro teacher upon watching herself/himself submitted a 2-3 page reflection discussing the details of the lesson by concentrating on the things went well or could be improved the next time and so forth. In addition to those data, the researcher asked six questions adhering to the trainees' video-mediated experiences at the end of the semester. In the light of the collected data, it was found that the pre-service teachers focused on numerous issues including teacher identity, linguistic abilities, teacher talk, task implementation, technology integration, and the efficacy of the materials. Such issues paved the way for combining these concepts with any real classroom application.

Video embedded studies can also be utilized with in-service language teachers. For example, Li (2013) conducted a study with a secondary school EFL teacher in China to explore the relationship between the teachers' beliefs and classroom practices. The participant was observed for four lessons (180 minutes), and a semi-structured interview was used to dig into her beliefs. The reflection component of the study was obtained through a video.The video recorded and transcribed lessons were analyzed through Conversation Analysis. The participant watched the selected parts of the classroom interaction and was requested to comment upon them. The data evidenced that there are both convergence and divergence between the espoused theories and theories practised by the participant. The study highlighted the importance of video-based reflection in assessing the match/mismatch between teachers' theories in mind and practice. The researcher concluded that it is tough to obtain information about teachers' beliefs and practices; nevertheless, reflecting upon their actions gives crucial insights into those specifically by the help of a video in this case.

\section{Contributions of Video Studies}

" Watching one's own video triggers a self-evaluation; thus, participants find an opportunity to discern what kind of areas they are good at or they need assistance: speaking skill, reading ability, the pronunciation of the words, fluency and other language-related domains.

" Videos provide an objective source of data rather than subjective comments, where actions in a video can verify each comment.

" Non-verbal communication aspect of teaching is essential just as much as verbal communication.Video records present body language, gestures and mimics of the participants more clearly and vividly. 
" The same video records may be utilized for various objectives. Observations through videos provide a permanent source where the actors can view the record at their disposal with multiple purposes.

" Practitioners can trace the changes in themselves on a specific issue by recording their teaching sessions at various intervals.

" Reflections on the same video record by multiple voices can generate fruitful discussions and interactions leading to a better learning and teaching context while contributing to the professional development of any partaker.

" Video records form a bridge between the theory and the practice. One can test whether her/his theories can be put into practice or whether a teacher acts in accordance with what s/he believes theoretically.

\section{Challenges in Conducting Video Studies}

" Participants may feel anxious due to the situation of being observed and recorded. This situation may cause the participants to demonstrate some actions that they normally do not perform or vice versa.

» Unexpected problems may arise during the recording session; the researcher may have to arrange another video session.

» Video-related equipment may be rather difficult to find or obtain due to the absence of such equipment within the immediate surroundings or because of financial limitations.

» Maintenance of the video records can be difficult; they can be lost or deleted after a while.

» Unlike other data collection tools, obtaining required permissions from the related authorities may not be feasible, or it may require a lot of effort and time.

\section{Recommendations for Conducting Video Studies}

» The researcher should obtain the written and signed permissions from the participants and the related partakers such as the school administration prior to the video recording session.

" The angle of the video should be arranged so that it focuses more on the teacher observed and her/his environment rather than the students depending on the objective. 
" Placing the video camera in one corner of the classroom -preferably at the back- can reduce the stress caused by the feeling of being observed.

"The camera and the related equipment (e.g., the battery) should be checked in the teaching environment prior to the video recording.

" Reflecting on a video should be compatible with the objectives of a lesson so the aims of the lesson should be specified at the onset.

" Depending on the objectives of the study, teacher trainees can wear a tieclip wireless microphone to be heard clearly while being observed through a video.

» Due to the ethical considerations, it is essential not to share the video records with the third parties.

» The researcher may invite one of her/his colleagues to take notes in case of any failure in a video shooting, especially when multiple recordings are not feasible.

» Immediately after the video recording session, it is highly recommended that the researcher should store the data in another device in order to sustain the maintenance of the original record.

\section{PORTFOLIO STUDIES}

Portfolios are regarded as educational measures in order to encourage learners to take responsibility for their own learning, as vehicles for understanding learning needs and for observing progress and performance in the course of their development (Heartel, 1990; Wiggins, 1993), and as alternative assessment tools involving a particular construction, implementation and evaluation processes (Smith \& Tillema, 1998; Wade \& Yarbrough, 1996; Wolf \& Dietz, 1991). A paper-based portfolio and an electronic portfolio (e-portfolio) are two major types. E-portfolio is a collection of work in an electronic format that displays the learning of students. Portfolios and e-portfolios have been extensively benefitted from within language learning and teaching contexts, which is the focus of this work. With the aim of promoting language education contexts, five representative portfolio studies are discussed in the following paragraphs.

How the portfolios supported pre-service teachers' learning to teach was investigated by Bataineh, Al-Karasneh, Al-Barakat, and Bataineh's (2007) study in which the portfolios provided pre-service teachers with productive learning experiences which help them develop their library use, knowledge, skills, attitudes, personality traits, motivation to learn, interpersonal relationships and 
an information source. The participants regarded the portfolio as a very effective tool in their learning to teach. This study implies that portfolios may serve valuable learning tools and have much to contribute to teacher training programs. The findings suggest that the participants in the study recognized the potential value of portfolios due to their reflective nature that would contribute to their professional development especially with regard to their library use, knowledge, skills, attitudes, personality traits, motivation to learn, interpersonal relationships and information source.

In the Turkish context, Yastıbaş and Yastıbaş (2015) investigated the effect of electronic-portfolios (e-portfolio) in English language teaching context. Their study aimed to find out whether e-portfolio-based assessment could be used to foster students' self-regulated learning by reviewing the existing literature. The analysis of the already existing literature displays that e-portfolio-based assessment can improve students' self-regulated learning in ELT. E-portfoliobased assessment enables students to become active participants in the learning process due to being decision-makers in every phase of portfolio keeping and creating process. Making decisions in every phase results in autonomous and responsible learning which encompasses one of the most significant contributions of e-portfolio-based assessment and self-regulated learning. An e-portfolio-based assessment provides students with classroom artefacts which serve as an indicator of their progress in learning. This indication is a sort of reflection which makes students understand and act on their weaknesses as well as strengths in their learning process.

In another study within the Turkish context, Ayan and Seferoğlu (2011) examined the role of electronic portfolios in fostering eight pre-service teachers' reflective thinking. The research was conducted with pre-service English language teachers who registered in a practicum course in an undergraduate teacher education program in Turkey. The participants here were asked to keep web-based electronic portfolios during the study. E-portfolios were claimed to give the participants sense ownership, to increase critical thinking, to highlight collaboration and to make associations between theory and practice. Also, these findings suggested that keeping electronic portfolios enhanced the participants' reflective thinking process. Based on this study, e-portfolios regarded as a part of Information Communication Technology (ICT) tools should be integrated into the pre-service teacher education programs as they significantly contribute to reflective thinking, authentic self-assessment, self-management, ownership over the learning process, empowerment and self-direction in learning in a constructivist learning setting.

In Orland-Barak's (2005) study, two different kinds of portfolios (referred to as 'process portfolio' and 'product portfolio') in two professional development 
courses for 32 mentors in Israel were analyzed to explore the quality of reflection associated with each type. The study showed that the language of practice and the form of reflection had significant similarities between the two uses of the portfolio, regardless of their differences in terms of content, purpose, organization and the degree of intervention of the course instructors in its construction. In these two types, the mentors described, to a large extent, their learning at technical levels of reflection. Such findings led to a questioning of the place of critical level reflective thinking to existing or not within a centralized Israeli educational context.

Similar to the findings of Orland-Barak's study, Viáfara González and Eugenia López (2011) discussed two EFL teachers' experiences related to the portfolio in an EFL education at the tertiary level with respect to the reflective thinking process. They embraced the portfolio study in their methodological procedures for ESP (English for Specific Purposes), academic literacy and teaching practicum courses. The portfolios were implemented for a period of six semesters in two private higher education institutions and a public university. Students were free in designing their own portfolios, whether paper or digital versions of portfolio. The participants were first through fourth-semester students of basic and pre-intermediate English courses delivered in different academic programs. These courses integrated mostly the principles of communicative language teaching, collaborative work, and autonomous learning. The teachers worked with textbooks, worksheets, CD-ROMs and language labs and the focus of the study, portfolios, were used as an alternative tool for assessment which was graded as part of students' classwork. The main objective of these courses was to enable learners to develop communicative competence in English, and accordingly portfolios acted a significant role to provide an opportunity for participants to select specialized material and expand their knowledge of jargon and subject matters in learners' majors. The findings revealed that at first students started ESP courses with low motivation to learn the language, nevertheless with the integration of portfolio caused an increase in the awareness of the importance of learning English. Also, the participants became aware of the variety of contexts in which English can be used, and the benefits that are learning this foreign language could bring to their lives. The digital type of portfolios was favoured much more than paper format since the digital version attracted their attention and satisfied their needs more. The implementation of portfolios in this study provided different options to work with portfolios and expanded the chances to involve students in natural communication as well as reflective learning.

\section{Contributions of Portfolio Studies}

" Portfolios serve as a record of student learning files electing learners' progress in language learning. Such record also enables instructors to monitor 
their students' progress in a concrete fashion. The portfolios can be used to visualize learners' progress and offer an authentic picture of learning.

" Portfolios, used as a form of alternative/authentic assessment, trigger learner-centred approach in an assessment which feeds any learner to take risks in the language learning process. Portfolio can compensate for the weaknesses of the traditional/conventional tests. While the traditional tests lack a full assessment involving the real picture of students' performance, portfolios, on the other hand, can assess any observable skill, knowledge or process of learners.

» Portfolios along with teachers' scaffolding can raise students' reflective and critical thing skills which especially emphasize one of the major assets of an effective teacher. Another advantage of using the portfolio assessment is the fact that students are exposed to a platform where they become independent thinkers as well as independent learners. This is mostly because students are supposed to actively participate in selecting their works to put in the portfolios during the process of completing portfolio assessment.

" Portfolio studies are not time and place-bound so that the participants can write at any time based on their availability.

" Portfolios improve students' writing skills, as well as their grammar and vocabulary knowledge.

" Portfolios play a crucial role in improving the research skills of language learners.

» Portfolios enhance personal skills and self-confidence.

" E-portfolios create incentives for learning by giving opportunities for learners to share various electronic sources such as PowerPoint presentations, blog and vlogs, photos, etc.

\section{Challenges in Conducting Portfolio Studies}

» Language instructors may find the assessment and evaluation process of the portfolios subjective and challenging.

» Most instructors find it hard to integrate portfolios into the curriculum due to time limitation during the academic year.

» The learners/teachers may not create a good habit for preparing files for their portfolios. 
" Due to its qualitative nature, the portfolio studies cannot be easily generalized since the data embraces individualized data open to subjective interpretations.

» Especially audio type learners may not have that sort of intelligence and zeal to create or write a file on the portfolio since their intelligence type is totally in a different zone.

\section{Recommendations for Conducting Portfolio Studies}

" The researcher should familiarize the participants with a portfolio keeping process. For this reason, modelling is a requirement for learners to observe a sample and get inspiration.

" To eliminate subjectivity in portfolio assessment, the use of an analytical rubric is recommended.

" Regular checks of portfolios are suggested in order to keep the participants on-task.

» For ensuring reliability, portfolio artefacts should be analyzed by another researcher/colleague as well.

" If possible, portfolios could be supported by another formative or summative assessment tool to better judge students' performance in language learning.

" Regular feedback sessions are recommended in order to inform students about their progress as well as to be able to act on the potential problems aroused during the portfolio keeping process.

\section{BLOG STUDIES}

Blogs, considered as one of the most common Web 2.0 tools, are used widely in almost any field from business to educational settings. Blogs are defined as online journals which may be updated by its users. Blogs are very easy to use, requiring only Internet access. In this digitalized era, people mostly use blogs to display their photos and post their audio and video files. Also, in line with this review content, blogs can highly be used for educational purposes, especially to improve English use. Since blogs require the users to write regularly and respond accordingly, the improvement of writing skill is inevitable. In addition to the writing skill improvement, learners' could also enhance their reflective thinking by communicating in and outside the class context naturally and by being exposed to teacher/peer interaction as well as teacher/peer feedback. Also, learners' research and study skills can be fostered via blogging. 
To start with the contribution of blogs to the writing skill, Featro and DiGregorio (2016) focused on the use of blogging utilized by ESL teachers. Graduate education students were supposed to write their experiences in US, K12 schools settings. This qualitative study investigated how blogs were used in the ESL classroom and focused on the pedagogical implications regarding the utilization of blogs in the ESL curriculum. Graduate education students aged between 23 to 45, at a private university in the northeastern part of the United States, were asked to fill out a survey about blogging in the ESL classroom. They were not expected to blog or lead blogging activities with students; however, they were asked to create reflective reports on blogging as a tool in an ESL context. The participants recorded how they observed blogs and reported their interviews with their mentors who used blogging in their ESL setting. After their observations and interviews, the participants evaluated the use of blogging in an ESL curriculum and teaching practices. The findings indicated that blogs enhanced classroom interaction and learning. The study also emphasized the obstacles, especially in preparing and integrating blogs into the ESL curriculum. Still, the participants insisted on integrating blogs into their future teaching settings for its highly improving students' writing skill which was not regarded as achievable in a conventional teaching context.

Within the Turkish context, Özkan (2011) in her study claimed that the blogging experience in pre-service language teacher education embraced both positive and negative aspects. The pre-service teachers focused on the effect of blogging in improving their writing skills as well as their critical thinking skills especially in writing responses to their peer's teaching performances in the methodology course where the study was conducted. Although this study involved more positive aspects in relation to blogging, the participants' voices with respect to the negativity of blogging experience should be taken into consideration, especially by other researchers in the field. Abuse of blogging and lack of objectivity specifically were listed on negative sides of blogging. The main contributions of blogging were enhancing writing and self-evaluation, providing a platform for the use of technology, reinforcing peer to peer feedback and communication. This facility also enabled participants to be exposed to an authentic context in a virtual world.

In another study conducted in Turkey, Arslan (2013) investigated the effect of blogging together with a portfolio on pre-service teachers' writing skill. The study comprised two terms in a compulsory writing course at ELT program in Turkey. The participants in the blog group posted all their written work on personal blogs, while the portfolio group kept personal portfolios for their written work. The study, quasi-experimental type, involved pre and post questionnaire, assessment of participants' essays at the beginning and end of the year, and teacher's continual feedback on the participants' written work. All participants 
completed pre and post questionnaire and by this means their progress in writing and their reaction to teacher and peer feedback in the writing course were analyzed. The participants in both blog and portfolio groups received feedback from the course instructor and their peers. The participants in this study regarded blogs and portfolio as invaluable tools, especially in triggering feedback giving and receiving process in and outside the classroom by making them practise the target language more in a natural setting. The study also displayed that the practice of blogging and portfolio keeping process and specifically receiving and giving feedback both on paper and online highly contribute to pre-service teachers' writing skills significantly. Process, organization, content, language use, vocabulary, mechanics, and accuracy were mostly improved domains according to the findings. Also, receiving teacher feedback was mentioned as the most favourite type compared to receiving and giving peer feedback. The study implies and stresses the integration of blogs and portfolios into writing classes in order to receive more benefits from the writing process in EFL contexts. Especially via blogging, students in EFL writing courses may benefit much from peer support as well as peer feedback.

In the related literature, blogs have been utilized with some other technological tools in educational settings. In Miyazoe and Anderson (2010), for example, the effectiveness of three different online writing activities- blogs, forums, and wikis- was investigated in formal university education with the aim of improving four language skills in an EFL-blended learning course in a university in Tokyo, Japan. This mixed-method design study sought answers to observe the potential impact(s) of these tools, how EFL learners perceived these tools and whether they were effective in their L2 attainment. Sixty-one sophomore students were exposed to the blended course flow involving weekly face-to-face instruction and out-of-class online writing activities. The participants used forums for topical discussions; they used blogs for an optional free writing activity, and they had wikis to do a translation in group work from English to Japanese. The students created both forums and blogs in English, and they used translation (from English into Japanese) on the wikis. Throughout the course, the course instructor just monitored the students doing online activities but did not join activities. In order not to influence the participants' writing, the instructor realized the analysis after the course. Once the study was completed, a survey was given to all the participants to receive their perceptions and experiences on the online tools. The survey displayed students' positive perceptions of the blended course design with online writings in which wikis were most favoured, followed by blogs and forums. Blogging, however, was most cited as a very enjoyable activity where the participants expressed much freedom in writing and posting blogs. 
Also, in English for Academic Purposes (EAP) contexts, blogs were found to be beneficial, especially in terms of improvement of writing and facilitation of peer feedback. To exemplify these contributions of blogs, Blackstone, Spiri and Naganuma (2007)'s study can be presented. Here in this study, they focused on a pedagogical perspective for blogging in ELT by examining the three teachers' experiences in EAP composition classes at a Japanese English-medium university. The authors implemented blogging and blog-related activities within four different EAP and composition courses involving four sequential levels during two semesters. The blogging procedure was initiated with a course set up to introduce blogging to students. Each student was assigned with a blogging buddy in order to check their posts before publishing. Blogging buddy in the study referred to a peer reviewer. Each student then was asked to post one blog every two weeks on an assigned topic, and each was also asked to read and respond three posts at least created by their peers during the two-week cycle. At the end of each academic term, a survey was given to all participants to elicit their views related to the blogging experience. The survey data involved four different topic areas including student attitudes toward writing, blogging as an in-class technique, peer reviews and being paired with blogging buddies. This study has a theoretical justification for the implementation of blogging and related activities within a university EAP and composition program with a comprehensive description of the design, operation and apparent benefits of blogging experience. The paper also presents and interprets findings from the attitudinal survey of 145 student bloggers. Blogs being digital and being accessible wherever students want attracted students' attention and blogs enhances learner centeredness rather than traditional teacher centeredness approach. Also, blogs triggered students to work autonomously based on their own grouping preferences which provided them with a platform open to peer cooperation and feedback. For these reasons, most of the participants in this study expressed their positive feelings towards blogging system and giving feedback via blogging. The study further implies the integration of blogging into ELT process since it triggers learner-centeredness, learner motivation and autonomous learning. For such reasons, the participants here regarded blogging as a communicative, productive and an effective way of using the target language in an ELT context.

\section{Contributions of Blog Studies}

" Blogs serve as a record of students’ progress in language learning.

» Blogs trigger a learner-centred approach in the English language learning process which signifies student responsibility and production.

» Blogs along with teachers' triggering guide questions, can raise students' reflective and critical thinking skills which especially emphasize one of the major 
assets of an effective teacher. They also motivate and engage students in higherlevel communicative learning.

" Blogs are reachable without any time and place limitation which provides freedom of accessibility.

" Blogs pave the way for the learners to write to a wider audience, so they find opportunities to improve their writing skills together with their grammar and vocabulary knowledge.

" Vlogs, much as they refer to non-authentic materials by language learners, can be fruitful especially in improving students' oral skills.

\section{Challenges in Conducting Blog Studies}

» Language instructors may find an assessment and evaluation process of the portfolios subjective and challenging. This may create a challenge for language practitioners.

» Students' posting improper or inappropriate comments/posts may be experienced.

» Due to its qualitative nature, the blog studies cannot be generalized since the data embraces individualized data open to subjective interpretations.

" Blogs by their nature are mostly public which means anyone could access to it and could manipulate data in a class blog.

» Planning time efficiently for blog and portfolio utilization is rather difficult for language instructors while following a certain syllabus and its content.

\section{Recommendations for Conducting Blog Studies}

» The researcher should familiarize the participants how to keep a proper blog. For this reason, course instructor/researcher should scaffold learners to proceed via blogging.

" Students should be given an opportunity to use a blogging and vlogging platform to publish course related images and give useful links related to English.

" Class blogs could be utilized in order to trigger extensive class activities which enable learners to use the target language in an authentic and a meaningful context. 
" Regular feedback for learners' posts on blogs is suggested in order to keep the participants on-task and keep their motivation high.

"An analytical rubric use is recommended for language instructors to eliminate subjectivity in portfolio assessment.

"With the aim of eliminating improper or inappropriate comments/posts, class teacher can always restrict comments to people in the class or to registered bloggers.

» In order to eliminate the access of the third parties and thus the manipulation of the data, privacy measurements can be taken by adjusting the setting of blogging.

» For reliability purposes, blog posts could be analyzed by another researcher or colleague as well.

» If possible, blogs could be supported by another authentic assessment tool in order to better evaluate learners' performance in the target language.

\section{CONCLUSION}

Reflectivity is one of the prevalent key concepts in every facet of education if 'change for the better' is the acknowledged motto for teachers' professional development. There are various reflective tools to be utilized in English language education, and this study focuses on four of these tools: diaries, videos, portfolios/e-portfolios and blogs. With the accompanying five representative research findings, each of these reflective tools is presented to be beneficial in paving the way for a better reflection and an enhanced language education context. The advantages of carrying out a study through these reflective tools are countless such as causing self-awareness in the individual, leading into skills development, sustaining a motive for a constant professional development, incorporating theory into practice, and tightening the bonds among all the actors within the context of education.

Besides the advantages, every research tool discussed in this paper has its own challenges as well. Being aware of such challenges brings out success, and this study aims at demonstrating those challenges followed by a few recommendations in order to eliminate or decrease these barriers in an educational context. By elucidating the advantages, challenges and the recommendations of the aforementioned reflective tools, the present study intends to serve as a concise yet constructive guide for the researchers aiming to conduct related studies. 
Overall, this study offers invaluable insights for English language learners, English language instructors, curriculum designers, textbook writers, and policymakers. To start with, learners could come up with the idea that their performance in L2 can be evaluated via reflective tools rather than conventional assessment types such as sit-down examinations. Besides, learners can more easily transmit their voices to other partakers in classroom discourse. Instructors, on the other hand, will be able to meet the needs of the individualized or selfdirected learning in a constructivist learning environment provided that they integrate such authentic and reflective tools into their practice. Also, such tools enrich the instructors' feedback and assessment types by providing a rich source of learner data. Curriculum designers also may benefit from the study that in integrating such tools into language assessment would facilitate the quality of the language education.

Textbook writers may include exercises or activities that would trigger learner reflection by using a variety of the aforementioned reflective tools. Only with this integration, learners can improve their critical thinking skills and strategies as well as their self-awareness. Policymakers might become aware of the positive impact of reflective teaching tools on learners' language development and transmit such ideas onto the regulations governing language education. It is widely acknowledged that once the educational policy -in any nation- was well established, its reflection to the other domains would be inevitable.

These reflective tools, proven to be beneficial by the studies reviewed, display that all stakeholders within ELT domain gain much regarding skills improvement, quality feedback, enhancement of critical thinking skills and research skills, authentic and meaningful communication in and out of classroom contexts what all these findings infer that language teachers cannot ignore the reality of introducing these tools to their learners as early as possible so that they become more competent and autonomous users of English.

\section{REFERENCES}

Arslan, R. S. (2013). Integrating feedback into prospective English language teachers' writing process via blogs and portfolios. Turkish Online Journal of Educational Technology-TOJET, 13(1), 131-150.

Ayan, D. and Seferoğlu, G. (2011). Using electronic portfolios to promote reflective thinking in language teacher education. Educational Studies, 37(5), 513-521.

Bailey, K. M. and Ochsner, R. (1983). A methodological review of the diary studies: Windmill tilting or social science? In K. M. Bailey, M. H. Long, 
and S. Peck (Eds.), Second language acquisition studies (pp.188-198). Boston: Heinle \& Heinle/ Newbury House.

Bataineh, R. F., Al-Karasneh, S. M., Al-Barakat, A. A. and Bataineh, R. F. (2007). Jordanian pre-service teachers' perceptions of the portfolio as a reflective learning tool. Asia-Pacific Journal of Teacher Education, 35(4), 435-454.

Black, G.L. (2015). Developing teacher candidates' self-efficacy through reflection and supervising teacher support. In Education, 21(1), 78-98.

Blackstone, B., Spiri, J. and Naganuma, N. (2007). Blogs in English language teaching and learning: Pedagogical uses and student responses. Reflections on English Language Teaching, 6 (2), 120. https://www.researchgate.net/publication/253230215_Blogs_in_Engli sh_language_teaching_and_learning_Pedagogical_uses_and_student_res ponses

Debreli, E. (2011). Use of diaries to investigate and track pre-service teachers' beliefs about teaching and learning English as a foreign language throughout a pre-service training program. Procedia-Social and Behavioral Sciences, 15, 60-65.

Dewey, J. (1933). How we think. New York: DC Heath.

Eröz-Tuğa, B. (2013). Reflective feedback sessions using video recordings. ELT Journal, 67(2), 175-183.

Farmer, B., Yue, A. and Brooks, C. (2008). Using blogging for higher order learning in large cohort university teaching: A case study. Australasian Journal of Educational Technology, 24(2), 123- 136. http://www.ascilite.org.au/ajet/ajet24/farmer.html

Featro, S. M. and DiGregorio, D. (2016). Blogging as an instructional tool in the ESL classroom. TESL-EJ, 20(1), 1-9.

Heartel, E. H. (1990). Performance tests, simulations and other methods. In J. Millman and L. Darling Hammond (Eds), The new handbook of teacher evaluation (pp. 278- 294). Newbury Park, CA, Sage.

Kır, E. (2012). Diary keeping in English lessons. Education Sciences, 7(4), 10821094.

Krishnan, L. A. and Hoon, L. H. (2002). Diaries: Listening to 'voices' from the multicultural classroom. ELT Journal, 56(3), 227-239. 
Lee, E. and Lew, L. (2001). Diary studies: The voices of nonnative English speakers in a master of arts program in teaching English to speakers of other languages. CATESOL Journal, 13(1), 135-149.

Li, L. (2013). The complexity of language teachers' beliefs and practice: One EFL teacher's theories. The Language Learning Journal, 41(2), 175-191.

Ma, R. and Oxford, R. L. (2014). A diary study focusing on listening and speaking: The evolving interaction of learning styles and learning strategies in a motivated, advanced ESL learner. System, 43, 101-113.

Miyazoe, T. and Anderson, T. (2010). Learning outcomes and students' perceptions of online writing: Simultaneous implementation of a forum, blog, and wiki in an EFL blended learning setting. System, 38(2), 185-199. https://doi.org/10.1016/j.system.2010.03.006

Orland-Barak, L. (2005). Portfolios as evidence of reflective practice: What remains 'untold'. Educational Research, 47(1), 25 - 44.

Orlova, N. (2009). Video recording as a stimulus for reflection in pre-service EFL teacher training. English Teaching Forum, 47(2), 30-35.

Özkan, Y. (2011). Blogging in a teaching skills course for pre-service teachers of English as a second language. Australasian Journal of Educational Technology, 27(4), 655-670.

Payant, C. (2014). Incorporating video-mediated reflective tasks in MATESOL programs. TESL Canada Journal, 31(2), 1-21.

Schön, D. A. (1984). The reflective practitioner: How professionals think in action. USA: Basic Books.

Smith, K. and Tillema, H. (1998). Evaluating portfolio use as a learning tool for professionals. Scandinavian Journal of Educational Research 42(2), 193205.

Susoy, Z. (2015). Watch your teaching: A reflection strategy for EFL pre-service teachers through video recordings. Procedia-Social and Behavioral Sciences, 199, 163-171.

Van Manen, M. (1991). The tact of teaching: The meaning of pedagogical thoughtfulness. Albany, SUNY Press.

Viáfara González, J. J. and Eugenia López, M. (2011). Portfolios across the EFL curriculum: Methodological perspectives of their use in university settings. 
Colombian Applied Linguistics Journal 13(2), 114-129. http://www.scielo.org.co/scielo.php?script=sci_arttext\&pid=S012346412011000200009\&lng=en\&tlng=en.

Wade, R. C. and Yarbrough, D. B. (1996). Portfolios: A tool for reflective thinking in teacher education?. Teaching and Teacher Education, 12(1), 63-79. Wiggins, G. (1993) Assessing student performance: Exploring the purposes and limits of testing. Jossey-Bass.

Wolf, K. and Dietz, M. (1998). Teaching portfolios: Purposes and possibilities. Teacher Educational Quarterly, 25(1), 9-22.

Yastıbaş, A. E. and Yastıbaş, G. C. (2015). The use of e-portfolio-based assessment to develop students' self-regulated learning in English language teaching. Procedia - Social and Behavioral Sciences, 176, 3-13. 